American Journal of Applied Sciences 6 (5): 995-1003, 2009

ISSN 1546-9239

(C) 2009 Science Publications

\title{
Estimating Snow Budget of Karaj Dam Reservoir
}

\author{
${ }^{1}$ Manijeh Ghahroudi Tali, ${ }^{1}$ Bohloul Alijani and ${ }^{2}$ Reza Sarvati \\ ${ }^{1}$ Department of Geography, Tarbiat Moallem University, No 49, Mofateh Ave, Tehran, Iran \\ ${ }^{2}$ Department of Geography, Shahid Beheshti University, Velenjak Ave, Tehran, Iran
}

\begin{abstract}
Problem statement: Most of the cold period precipitation of Karaj Basin falls in the form of snow. This snow and its run off are important to the dam and the local needs such as agriculture and the drinking water of Tehran. But due to the scarcity and in some elevations the lack of weather stations, measuring this snow cover and its run off is difficult. We have decided to estimate the amount of this snow cover by using surrogate methods such as satellite images of MODIS and temperature thresholds. Approach: To estimate the snow water budget of the Karaj Dam Reservoir Basin, first a temperature threshold of $3^{\circ}$ Celsius was defined according to the analysis of daily temperature and precipitation values of Nesa station during 1960-2000. The elevation of this temperature was as low as $1590 \mathrm{~m}$ in February and $5734 \mathrm{~m}$ in August. During each month the melting snow was computed over the area between 3 and zero degrees Celsius and precipitation below zero degrees was considered as permanent snow cover. The precipitation of areas above $3^{\circ}$ was computed as rain. Using this temperature threshold and the DEM map of the basin we estimated the snow cover and snow melt water of the basin. The snow cover area on the MODIS images was estimated and compared with that computed from temperature threshold. Both methods gave relatively similar results. At the end the snow melt water of the whole cold period was calculated and added up to estimate the total snow water budget. Results: The results showed that during the study months most $(67.7 \%)$ of the precipitation comes in the form of snow. And most of this snow (97.5\%) melts during months March and onward. Its monthly distributions are 3.8\% in March, 22.7\% in April and 71\% in May. The total snow water entering the dam was about 181.73 million cubic meters. Conclusion: The comparison of the results from temperature thresholds with the MODIS images snow cover showed very little and negligible discrepancy. Therefore, this study confirmed the use of these images as a tool for defining snow cover and snow melt water computations. This finding is very important for the mountainous areas with few scattered or no weather stations.
\end{abstract}

Key words: Snows melt water, MODIS images and snow cover computations, GIS and snow budget, snow line temperature threshold

\section{INTRODUCTION}

Most of the dams are built mainly for two purposes: Gathering and managing the local run off especially during flood periods is the main objective and the electricity production as the second one. The Karaj Dam built upon the Karaj River on the southern slopes of the Alborz Mountains, serves both objectives. Due to the semi arid nature of the climate of the area ${ }^{[1]}$ and the mountainous location of the dam (Fig. 1), the precipitation and hence the water level of the reservoir varies very much within the year and through the time. This makes it difficult to manage the water retained behind the dam. The sudden torrential floods of spring months due to rapid melt of the accumulated snow from cold winter months are always a threat for the dam. On the other hand, the area, especially the over populated capital city of Tehran, suffer from water shortage during warm summer months. Therefore it is a vital necessity to manage the run off of the basin in a way to prevent the spring flood hazards and at the same time to reserve water for the warm period needs. This planning necessity relies mostly on the management and monitoring of the snow budget of the basin. Because the basin is a mountainous and rugged area ranging from as low as $1660 \mathrm{~m}$ elevation in the lower parts to the $4318 \mathrm{~m}$ in the upper parts. Thus, most of the wet period experience very low temperatures. As a result,

Corresponding Author: Manijeh Ghahroudi Tali, Department of Geography, Tarbiat Moallem, University, No. 49, Mofateh Ave, Tehran, Iran Tel: +982122264097 Fax: +982188433731 


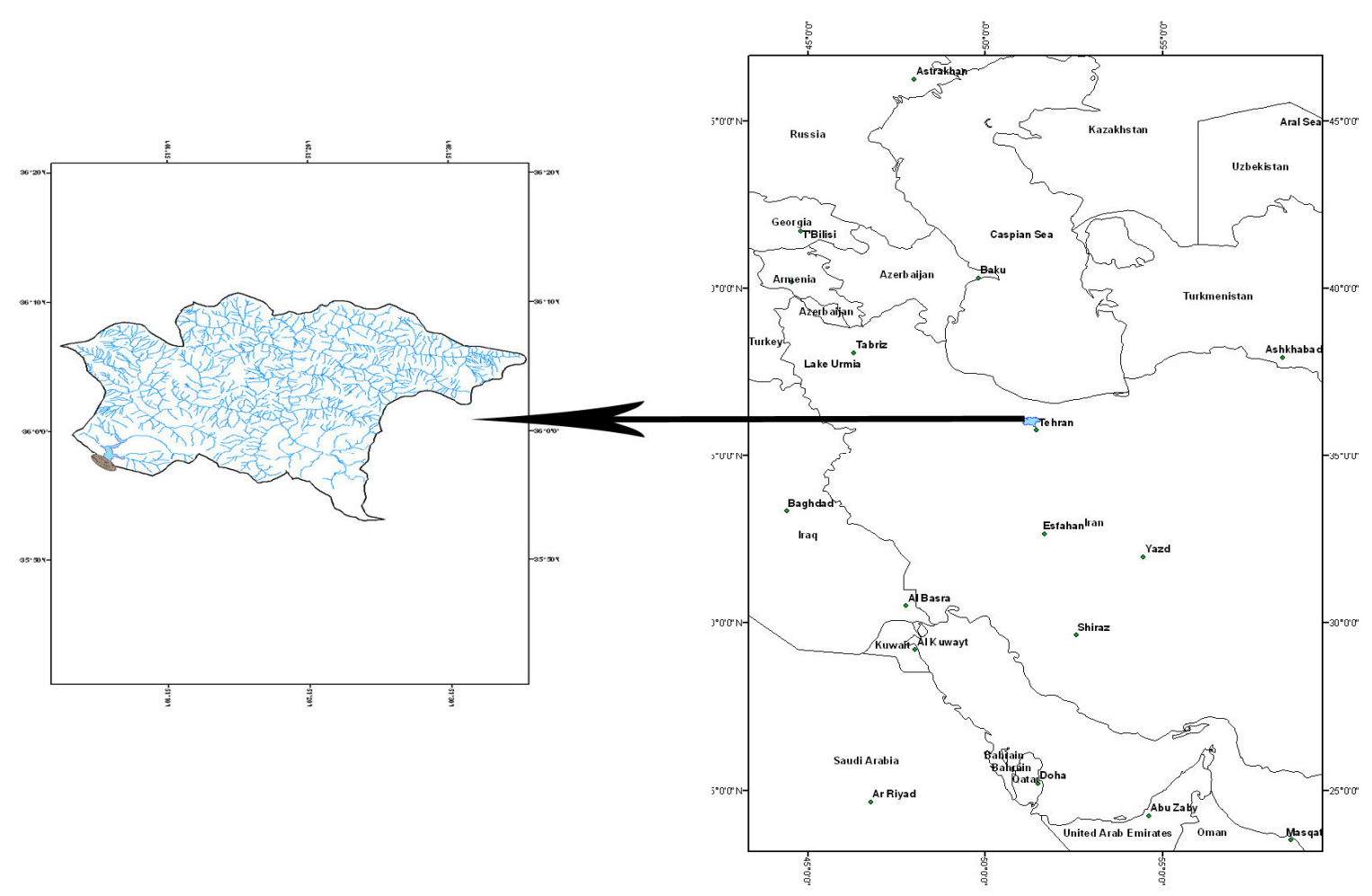

Fig. 1: Karaj dam basin in Iran

a reasonable part of the precipitation comes in the form of snow. Snow is much more important in the river discharge than the rainfall. Because snow remains on the surface for long time and melts slowly making the river discharge permanent. Regular and direct measurement of snow is difficult, especially on the higher elevations and during very cold and snowy season.

The sudden melt of this snow during late winter or early spring time causes sever problems. The relatively small basin area of $842592500 \mathrm{~m}^{2}$ is a limiting factor for the run off management of the area and should be considered very seriously by the planners. There fore this study tries to measure the snow budget of the basin and develop a model to manage it. This task requires dense snow measuring stations distributed mostly over the higher mountains. Establishing and monitoring these stations is some-what difficult, because working in these high altitudes during snowy and cold periods of the year is very difficult and more expensive. On the other hand there are not enough stations in these high altitudes. As a result, in most countries, snow depth and variations is monitored indirectly. The development of sophisticated remote sensing instruments and techniques has provided correct and precise indirect methods for monitoring and studying snow cover.

Different snow sensors such as MSS TM, ETM Landsat, AVHRR/NOAA, MODIS/TERRA, SAR and SSM/I are active now. Snow-cover maps of the Northern Hemisphere have been available since 1966 from these sensors. In the continuation of these efforts, the NOVAA satellite was launched in $1977^{[2]}$. The images of this and other satellites are used to estimate snow cover of the earth surface ${ }^{[3]}$. In 1998 the MODIS was launched from Terra EOS AM-1 to record the variations of Earth's surface in 36 bands. It has an AVHRR sensor to monitor climatic variations, including snow cover ${ }^{[4]}$. Snow cover is identified on these images mostly through its reflection in visible and Infrared bands ${ }^{[5,6]}$.

Salomonson and Appel ${ }^{[7]}$, used NDSI to identify the snow cover. They identified a pixel as snow if the NDSI was greater than 0.4 and the reflectance of it in band 2 greater than $0.11 \%$ and in band 4 greater than $0.1 \%$. But Sumahak and Poon ${ }^{[8]}$ in studying the snow cover of northern forests of Manitoba on the MODIS images, in addition to NDSI used the following criteria: 
- The difference of NDVI and NDSI should be in the snow area

- The reflection of the pixel in band 2 should be more than $0.11 \%$

- The reflection of the pixel in band 4 should be more than $0.1 \%$

- Recently, some researchers have used MODIS (Moderate Resolution Imaging Spectroradiometer) images of 2.5 to 4 micrometer for definition of snow and vegetation indices ${ }^{[9,10,11]}$. The results showed improvements in measuring and monitoring snow budget of the basins. It is obvious that direct monitoring of snow cover of the basin is indeed impossible. Therefore this research has decided to use the indirect methods such as satellite images and temperature thresholds to measure the snow melt water in the Karaj Dam Basin

\section{MATERIALS AND METHODS}

Determining snow cover: To define the snow budget of the basin we used two methods of temperature threshold and satellite images. The satellite images were used mainly as the proof of the temperature threshold method. In order to determine a threshold for the snow fall, we analyzed the daily temperature and precipitation of Nesa station (Fig. 2). The lowest temperature of snowy days of this station was defined as the temperature threshold for snow cover. This threshold was checked with the snow cover observed on the satellite images.

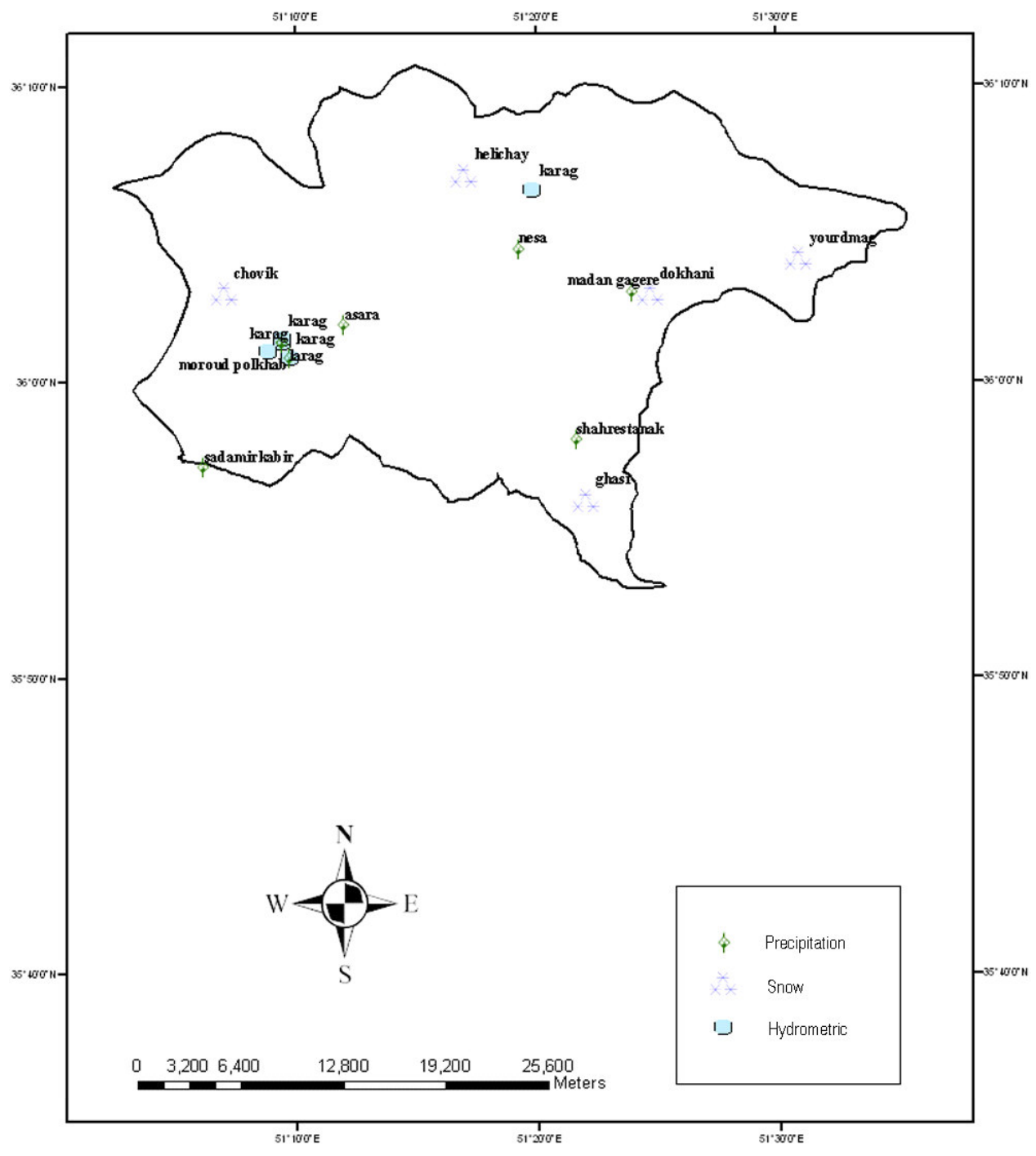

Fig. 2: Studied stations

997 
Am. J. Applied Sci., 6 (5): 995-1003, 2009

Snow cover on the satellite images was determined as follows:

- The satellite images of MODIS were selected from the available period of 2005-2007 for the normal snowing months of December to April

- Of thirty six bands of the sensor of MODIS only bands $2(0.841-0.876 \mu \mathrm{m}), 4(0.545-0.565 \mu \mathrm{m})$ and $6(1.628-1.652 \mu \mathrm{m})$ were used. The spatial resolution of these bands are $250 \mathrm{~m}$ in band 2 and $500 \mathrm{~m}$ in the bands 4 and 6 . To improve the spatial resolution, these bands with different scales were fused. Then the Normalized Difference Snow Index (NDSI) was calculated using the bands 4 and 6 as follows:

NDSI $=$ MODIS $(0.545-0.565 \mu \mathrm{m})$-MODIS (1.628$1.652 \mu \mathrm{m}) / \mathrm{MODIS} 4+\mathrm{MODIS6}$

According to this equation any pixel with NDSI $>0.4$ was defined as snow area

- Although NDSI is a common index to determine snow from other natural land covers, but it has difficulty in differentiating the snow from other moist features such as water. To improve the efficiency of NDSI, the reflectivity coefficient of bands 2 and 4 were used. Because in these bands snow has the reflectivity more than $10 \%$ while water has much less than $10 \%$. As a result, any pixel with reflectivity higher than $11 \%$ in band 2 and $10 \%$ in band 4 , was classified as snow covered pixel. Each pixel was defined as an area of 50 by $50 \mathrm{~m}$

- The final definition of snow cover on the MODIS images was achieved when the following conditions were present collectively:

$$
\text { NDSI }>=0.4 \text {, }
$$

MODIS band $2>11 \%$ and

MODIS band $4>=10 \%$

These criteria are not applicable on the images of cloudy days ${ }^{[12]}$. Therefore we extracted the clear sky images which counted to eight images in March months.

The defined criteria were applied to all pixels of the images using the Raster Calculator of the ArcGIS Environment. The confirmed temperature threshold of snow cover was used to define the snow area on the DEM map of the basin for the whole study period. For this purpose, the daily temperatures of all 13 stations (Fig. 2) of the basin were used. The monthly precipitation and temperature of these stations are shown in Table 1 and 2 respectively. Most of the winter precipitation comes in the form of snow. In order to define the monthly lower limit of snow cover,
Table 1: Monthly precipitation of the stations

\begin{tabular}{lrrcccr}
\hline Station & Dec. & \multicolumn{1}{c}{ Jan. } & \multicolumn{1}{l}{ Feb. } & \multicolumn{1}{c}{ Mar. } & \multicolumn{1}{c}{ Apr. } & \multicolumn{1}{l}{ May } \\
\hline Siyera karaj & 81.12 & 64.17 & 83.06 & 102.25 & 88.28 & 71.46 \\
Moroud polkhab & 83.03 & 58.69 & 73.16 & 94.59 & 88.90 & 78.41 \\
Nesa & 80.12 & 61.81 & 77.44 & 90.3 & 90.34 & 84.03 \\
Shahrestanak & 68.44 & 56.98 & 70.61 & 80.14 & 89.76 & 90.36 \\
Sadamirkabir & 56.18 & 46.99 & 50.85 & 59.42 & 56.54 & 54.07 \\
Madan gagere & 59.45 & 45.96 & 50.64 & 71.46 & 76.73 & 96.05 \\
Asara & 70.63 & 57.38 & 64.78 & 70.64 & 68.63 & 73.28 \\
Siyera & 81.12 & 64.17 & 83.06 & 102.25 & 88.28 & 71.46 \\
Chovik & 16.91 & 86.13 & 167.58 & 224.91 & 82.82 & 2.16 \\
Yourdmag & 110.93 & 220.47 & 347.73 & 512.78 & 509.53 & 193.24 \\
Ghasr & 26.76 & 92.78 & 165.16 & 234.60 & 93.76 & 0.00 \\
Dokhani & 24.22 & 105.07 & 181.71 & 253.89 & 178.16 & 5.53 \\
Helichay & 20.84 & 116.96 & 203.76 & 263.53 & 131.00 & 3.30 \\
\hline
\end{tabular}

Table 2: Mean monthly temperature of the stations

\begin{tabular}{lrrrrrr}
\hline Station & Dec. & \multicolumn{1}{c}{ Jan. } & \multicolumn{1}{c}{ Feb. } & Mar. & \multicolumn{1}{c}{ Apr. } & \multicolumn{1}{c}{ May } \\
\hline Nesa & -0.11 & -3.79 & -4.76 & -0.79 & 4.82 & 10.54 \\
Shahrestanak & -0.69 & -3.78 & -5.25 & -0.06 & 5.01 & 11.04 \\
Sadamirkabir & 5.37 & 2.21 & 1.77 & 5.40 & 10.98 & 15.50 \\
Madangagere & -0.63 & -4.79 & -6.67 & -2.96 & 2.66 & 9.29 \\
Asara & 1.21 & -4.26 & -4.16 & 1.14 & 5.86 & 10.96 \\
\hline
\end{tabular}

a regression equation was computed between the monthly temperature and elevation of the stations. The resulted regression equation of each month was applied to the DEM of the basin in the Raster Calculator of ArcGIS Environment ${ }^{[13]}$. This was done to determine the area of the basin located within or outside of the snow temperature threshold line. In this way the amount of snow retained or melted in each month was defined.

The mean monthly precipitations of 13 stations were used to interpolate the spatial distribution of the basin's precipitation budget. This interpolation was done in the ArcGIS environment using the IDW method.

The interpolated precipitation and the DEM maps with temperature threshold isolines of each month were overlaid. In each month, the area of the snow melt was determined and the amount of melt water was computed. The snow melt area was defined as the area above zero degrees Celsius. The procedure is outlined:

$$
\mathrm{R}=\sum \mathrm{w}_{\mathrm{i}}+\sum \mathrm{s}_{\mathrm{i}}
$$

where, $\mathrm{w}_{\mathrm{i}}$ is the melt water of each pixel located in the snow melt area of the present month, $s_{i}$ is the melt water of the pixel from last month snow, which is located in the snow melt area of the present month. The $\sum \mathrm{s}_{\mathrm{i}}$ is zero for the first snowy month. The computation of snow melt water started from the first snowy month, December.

The water budget of the pixels outside the snowy area was computed as rain ${ }^{[14]}$. The total water budget of the basin in each month was considered as the sum of the 
rainfall of pixels outside snow area and melt water of the snow area. The melt water of the snow area was computed as the equivalent water of the melted snow ${ }^{[15]}$.

Soil water retention: The run off of the basin is resulted after the soil retention was removed from the basin precipitation budget. The soil water retention (S) was computed using the United States Soil Conservation Service Curve Number method as follows:

$$
\mathrm{S}=(25400 / \mathrm{CN})-254
$$

where, $\mathrm{CN}$ is the curve number computed according to the characteristics of the basin through a weighted model ${ }^{[16]}$. Each characteristic has developed a layer with especial weight in our model. These layers are as follows:

- Geological map of the basin is classified according to its water retention potential. The basin is composed of calcic rocks and alluvial deposits ${ }^{[17]}$. Each rock type is given a weight according to its water retention potential
- Normalized Difference Vegetation Index (NDVI) of the basin is extracted from LISSIII IRS images and made a layer with four classes of water retention potential ${ }^{[18]}$. Most of the vegetation is composed of fruit gardens in the river basins and rest of the area is void of vegetation (Fig. 3a)

- According to the field observations and supervised fusion of LISSIII IRS and panchromatic images, land use types of the basin were determined (Fig. 3b). This fusion is done to improve the spatial resolution of LISSIII IRS images

- Drainage density of the basin was another layer used in computing $\mathrm{CN}$ value of the basin. This layer was extracted according to Strahler Model installed in the ArcGIS environment ${ }^{[19]}$ and was divided into four classes (Fig. 3c). The lowest density class was given the highest weight. Because the lower the drainage density the higher the amount of run off

- The hydrological soil groups of the basin were defined according to Table 3 indices. The resulted map is shown in Fig. 3d

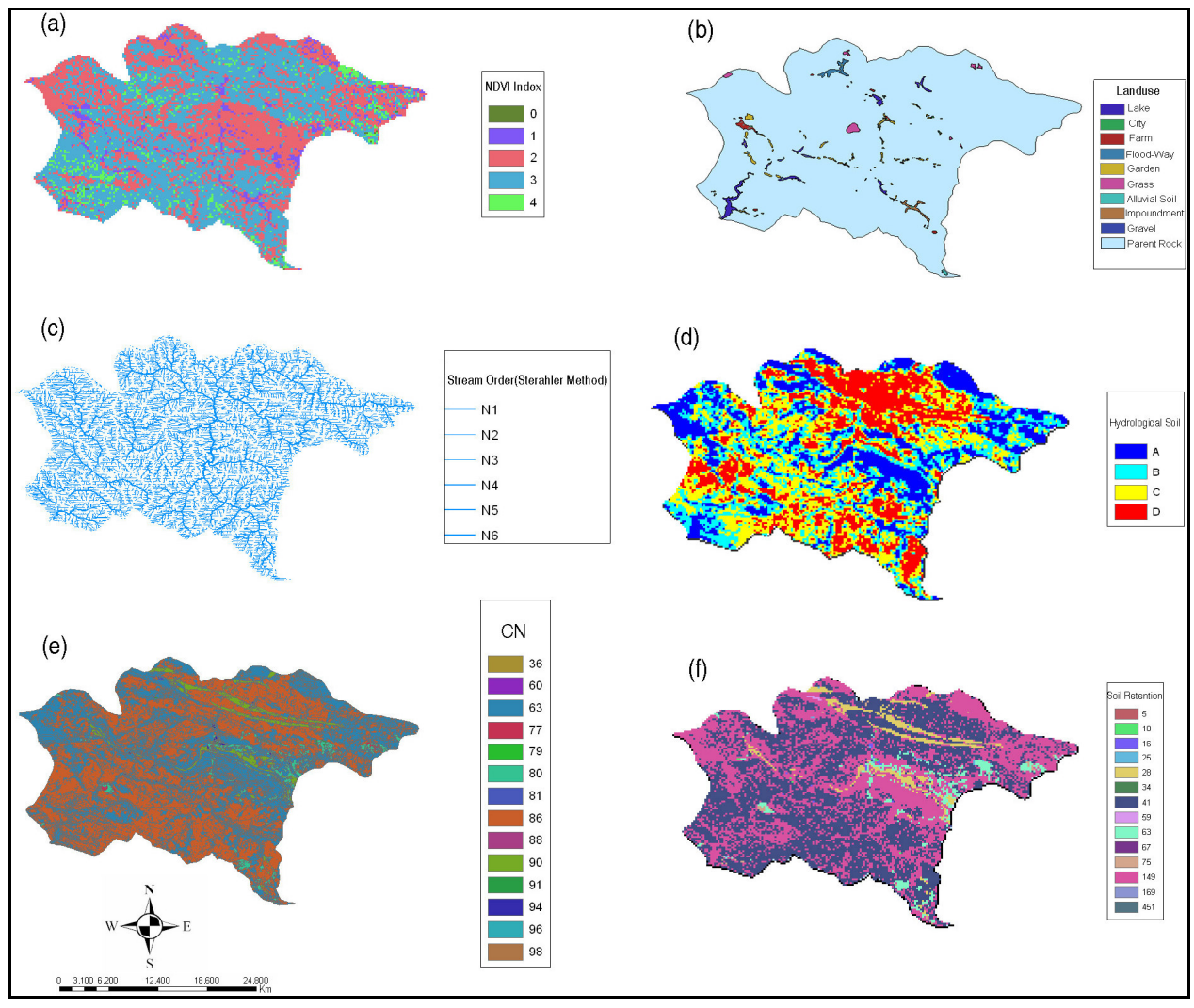

Fig. 3: (a): NDVI Index; (b): Land use Map; (c): Drainage Densityand; (d): Hydrological Soil Groups; (e): Curve Number $(\mathrm{CN})$ and $(\mathrm{f})$ : Water Soil retention 
Am. J. Applied Sci., 6 (5): 995-1003, 2009

Table 3: The standard for the classification of hydrological soil groups in Karaj Dam Reservoir

\begin{tabular}{lllll} 
& & Hydrological soil groups & & \\
Soil characteristics & A & B & C & D \\
\hline Texture & Sand-Gravel & Moderately coarse to fine & Five to very fine & Clay \\
Depth & Deep & Moderately deep & Moderately deep & Shallow \\
Drainage & Excess & Well & Moderately deep & Slow \\
Water transmission & High & Moderate & Slow & Very slow \\
Infiltration rate & High & Moderate & Slow & Very slow \\
Run off potential & Low run off & Moderate run off & Moderate run off & High run off \\
\hline
\end{tabular}

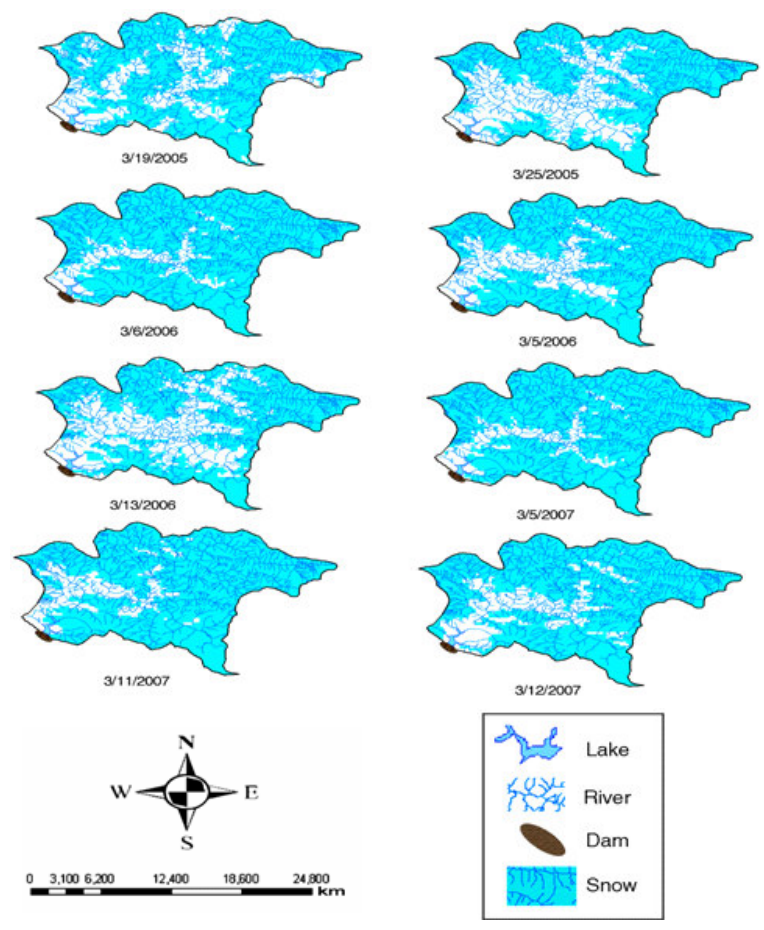

Fig. 4: Snow area delineated on the MODIS images

Using these layers the $\mathrm{CN}$ value was calculated for each pixel (Fig. 3e). The $\mathrm{CN}$ value of the total basin was calculated as:

$$
\mathrm{CN}=\sum \mathrm{cn}_{\mathrm{i}} * \mathrm{a}_{\mathrm{i}} / \sum \mathrm{a}_{\mathrm{i}}
$$

Where:

$\mathrm{cn}_{\mathrm{i}}=$ The $\mathrm{CN}$ of each pixel

$\mathrm{a}_{\mathrm{i}}=$ Its area

Using this equation the annual soil water retention of each pixel was computed (Fig. 3f).

The resulted soil water retention was divided among the months with temperatures above zero degrees Celsius. Because in months with temperature below zero there is no water running on the basin. The resulted monthly soil water retention was subtracted from the month's precipitation and the amount of the run off was determined.
Snow melt from MODIS images: The snow cover area was extracted on the MODIS images and their snow melt water was computed according to defined temperature thresholds. The images for month March are shown in Fig. 4.

\section{RESULTS}

From all MODIS images only eight clear sky images were found for March months. These images were used as an index for defining the snowy area. The outlined conditions were applied to these images and the resulted snowy area is shown in Fig. 4. On the other hand, the inspection of the daily temperature and precipitation values of Nesa station showed that snow comes mostly on the days with temperature below $-3^{\circ}$ Celsius. This threshold was checked on the eight MODIS images. The comparison of the results confirmed the $3^{\circ}$ Celsius threshold. Therefore this threshold was used as an isoline encircling the snowing area in the basin.

The results of the regression between monthly temperature and elevation are shown in Table 4.

According to Table 4 the lowest limit of snow cover is $1214 \mathrm{~m}$ in January and the highest is $5234 \mathrm{~m}$ in August. The snow melting line of zero degrees Celsius is as low as $1590 \mathrm{~m}$ in February and as high as $5734 \mathrm{~m}$ in August. As it is clear from Fig. 5, during January and February the entire basin is covered by snow. Because the temperature is below zero degrees celcius over the entire basin. The permanent snow cover decreased towards the spring months so that in May the entire basin was out of the snow cover. Therefore during this month all of the snow was melted. In each month the area bounded between 3 and zero degrees was designated as the snow melting area and its total water was computed.

Water budget of the basin: The combined maps of interpolated precipitation and DEM of the area are shown in Fig. 6 and the calculated amounts of water budget are shown in Table 5 . 
Am. J. Applied Sci., 6 (5): 995-1003, 2009

Table 4: Temperature (T) - elevation (h) regression models

\begin{tabular}{|c|c|c|c|c|}
\hline Month & Equation & Correlation & $\begin{array}{l}\text { Height } \\
\text { corresponding } \\
\text { to } 0^{\circ}\end{array}$ & $\begin{array}{l}\text { Height } \\
\text { corresponding } \\
\text { to } 3^{\circ}\end{array}$ \\
\hline October & $\mathrm{T}=(24.897-6) 10^{--} 3 \mathrm{~h}$ & -0.82 & 4149 & 3649 \\
\hline November & $\mathrm{T}=(18.646-6) 10^{--} 3 \mathrm{~h}$ & -0.94 & 3107 & 2607 \\
\hline December & $\mathrm{T}=(13.519-6) 10^{--3} 3 \mathrm{~h}$ & -0.82 & 2253 & 1753 \\
\hline January & $\mathrm{T}=(10.288-6) 10^{--} 3 \mathrm{~h}$ & -0.82 & 1714 & 1214 \\
\hline February & $\mathrm{T}=(12.727-8) 10^{--} 3 \mathrm{~h}$ & -0.94 & 1590 & 1215 \\
\hline March & $\mathrm{T}=(17.565-8) 10^{--} 3 \mathrm{~h}$ & -1.00 & 2195 & 1820 \\
\hline April & $\mathrm{T}=(22.314-8) 10^{--} 3 \mathrm{~h}$ & -1.00 & 2789 & 2414 \\
\hline May & $\mathrm{T}=(23.547-6) 10^{--} 3 \mathrm{~h}$ & -0.94 & 2943 & 3924 \\
\hline June & $\mathrm{T}=(30.258-7) 10^{--} 3 \mathrm{~h}$ & -0.94 & 4322 & 3894 \\
\hline July & $\mathrm{T}=(34.265-7) 10^{--} 3 \mathrm{~h}$ & -0.94 & 4895 & 4466 \\
\hline August & $\mathrm{T}=(34.408-6) 10^{--3} \mathrm{~h}$ & -0.94 & 5734 & 5234 \\
\hline September & $\mathrm{T}=(31.105-6) 10^{--3} \mathrm{~h}$ & -0.94 & 5184 & 4684 \\
\hline
\end{tabular}

Table 5: Water budget of the basin

\begin{tabular}{|c|c|c|c|c|}
\hline $\begin{array}{l}\text { Volume of } \\
\text { water(m3) }\end{array}$ & $\begin{array}{l}\text { water deptl } \\
\text { in } \mathrm{mm}\end{array}$ & $\operatorname{AREA}\left(\mathrm{m}^{2}\right)$ & Parameter & Months \\
\hline 52482700 & 70.8036 & 741242000 & Snow retained & December \\
\hline 48311.6 & 28.4440 & 1697500 & rain & December \\
\hline 4191240 & 42.7232 & 98102500 & snow melt & December \\
\hline 41774800 & 49.6200 & 841887000 & Snow retained & January \\
\hline 0 & 0.0000 & 0 & rain & January \\
\hline 5708.17 & 20.7600 & 275000 & snow melt & January \\
\hline 31147400 & 36.9800 & 842162000 & Snow retained & February \\
\hline 0 & 0.0000 & 0 & rain & February \\
\hline 0 & 0.0000 & 0 & snow melt & February \\
\hline 19256000 & 25.1700 & 765148000 & Snow retained & March \\
\hline 158280 & 27.3100 & 5795000 & rain & March \\
\hline 2056540 & 28.8700 & 71220000 & snow melt & March \\
\hline 16632800 & 38.9600 & 426867000 & Snow retained & April \\
\hline 4667720 & 25.89 & 180272000 & rain & April \\
\hline 5525340 & 23.5000 & 235150000 & snow melt & April \\
\hline 0 & 0.0000 & 0 & Snow retained & May \\
\hline 20521700 & 39.5300 & 519187000 & rain & May \\
\hline 23321500 & 72.2000 & 323015000 & snow melt & May \\
\hline
\end{tabular}

According to Table 5, in December, the first snowy month, of $842592500 \mathrm{~m}^{2}$ basin area only $98102500 \mathrm{~m}^{2}$ are in the melting realm. This area produced $4191240 \mathrm{~m}^{3}$ water. The rainy area produced only $48311.6 \mathrm{~m}^{3}$ water. As a result in December 4239551.6 $\mathrm{m}^{3}$ water was produced in the basin. The snow retained area increased during next months covering all of the basin in February. Therefore there was no snow melt water in months January and February. The water budget of January was only $5708.17 \mathrm{~m}^{3}$ from melting snow. February did not produce any water in the whole basin.

Due to warming of the atmosphere, the snow melting area in March increased to $71220000 \mathrm{~m}^{2}$ and rainy area to $5795000 \mathrm{~m}^{2}$ (Fig. 6) producing 2056540 $\mathrm{m}^{3}$ and $158280 \mathrm{~m}^{3}$ water respectively. In this month some of the snow of the previous months was melted summing to $4690057 \mathrm{~m}^{3}$ (Table 6). Adding this amount to the month's own water, the drainage of the basin in March is $6904877 \mathrm{~m}^{3}$.
Table 6: Water added from previous months

\begin{tabular}{lll}
\hline Month & Area $\left(\mathrm{m}^{2}\right)$ & Water $\left(\mathrm{m}^{3}\right)$ \\
\hline March & 76862500 & 4690057 \\
April & 235150000 & 31033541 \\
May & 323015000 & 85510800 \\
\hline
\end{tabular}

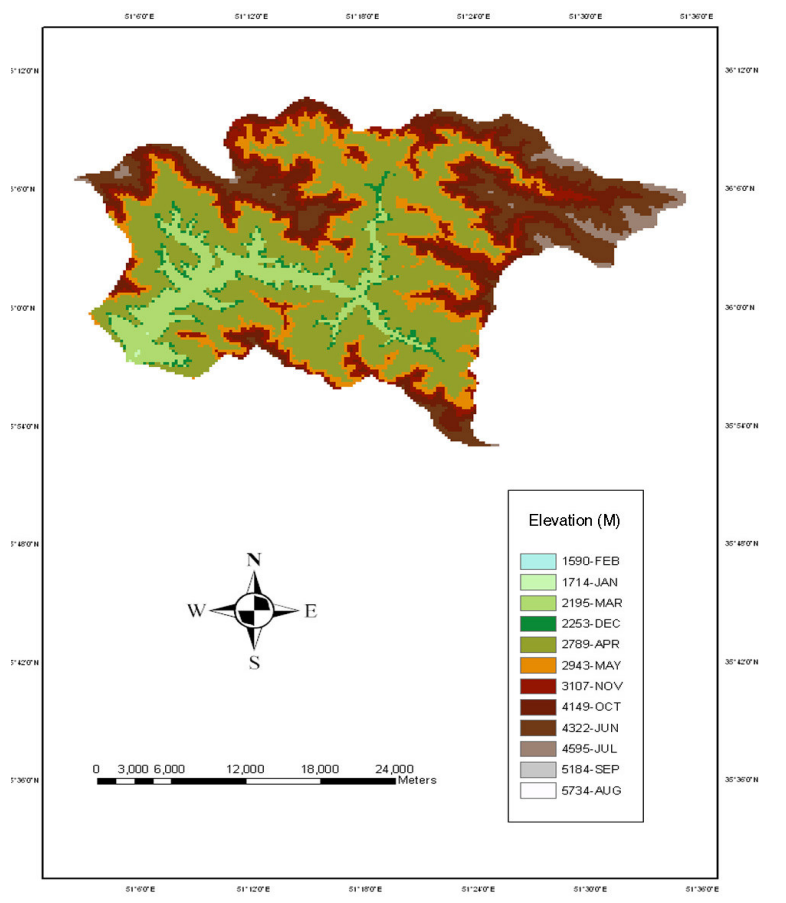

Fig. 5: The elevation of -3 degrees Celsius in different months

The warming process continued to the next months so that in April both snow melt and rainy areas increased lowering the snow retained area to about half of the basin. The total water resulted from melting snow and rain summed to $10193060 \mathrm{~m}^{3}$. The water added from previous months was $31033541 \mathrm{~m}^{3}$. Thus the total water budget of the basin was $41226601 \mathrm{~m}^{3}$.

In May all of the basin located above zero degrees Celsius and all of its snow was melted, producing $43843200 \mathrm{~m}^{3}$ water. The water from previous months amounted to $85510800 \mathrm{~m}^{3}$. As a result, all of the water budget of the basin was added up to $129354000 \mathrm{~m}^{3}$. This is the amount of water budget that is produced in the basin. But some of it will be retained by soil and some will evaporate before reaching the dam.

Soil Water retention: Using the method and procedure outlined in the Methods section the total soil water retention of the annual precipitation of the basin was calculated as $73623090 \mathrm{~m}^{3}$ which equals to $87 \mathrm{~mm}$ water depth over the whole basin for the whole year. 
Am. J. Applied Sci., 6 (5): 995-1003, 2009

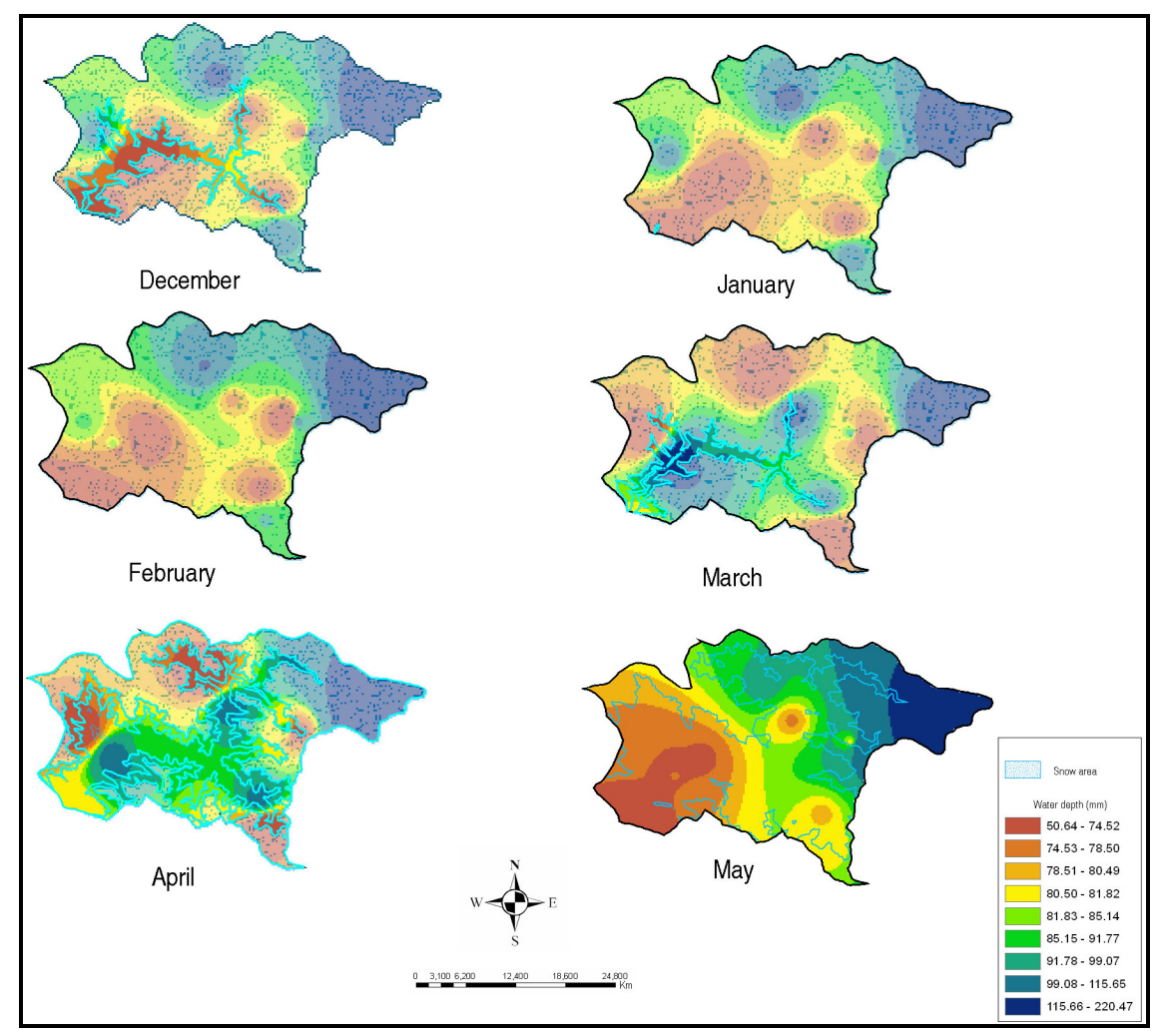

Fig. 6: Snow retained and melt area in different months

Table 7: Run off calculations of the basin

\begin{tabular}{lrlrlr}
\hline Month & $\begin{array}{l}\text { Total } \\
\text { water } \\
\left(\mathrm{m}^{3}\right)\end{array}$ & $\begin{array}{l}\text { Total } \\
\text { water } \\
(\%)\end{array}$ & $\begin{array}{l}\text { Water } \\
\text { depth } \\
(\mathrm{mm})\end{array}$ & $\begin{array}{l}\text { Soil } \\
\text { retention } \\
(\mathrm{mm})\end{array}$ & $\begin{array}{l}\text { Run } \\
\text { off } \\
(\mathrm{mm})\end{array}$ \\
\hline December & 4239551.60 & 2.300 & 5.030 & 0 & 5.030 \\
January & 5708.17 & 0.003 & 0.008 & 0 & 0.007 \\
February & 0.00 & 0.000 & 0.000 & 0 & 0.000 \\
March & 6904878.00 & 3.800 & 8.200 & 10 & 1.800 \\
April & 41226601.00 & 22.700 & 48.930 & 10 & 38.930 \\
May & 129354000.00 & 71.200 & 153.520 & 10 & 143.520 \\
\hline
\end{tabular}

Table 8: Snow equivalent water computed from MODIS image

\begin{tabular}{llll}
\hline Date & Area $\left(\mathrm{m}^{2}\right)$ & Area $(\%)$ & $\begin{array}{l}\text { Snow water } \\
(\text { only March })\left(\mathrm{m}^{3}\right)\end{array}$ \\
\hline March 5, 2007 & 741235000 & 87.96 & 186568850 \\
March 8, 2006 & 660670000 & 78.40 & 166290639 \\
March 11, 2007 & 714472500 & 84.80 & 179832728 \\
March 12, 2007 & 702087500 & 83.30 & 176715424 \\
March 13, 2006 & 618137500 & 73.30 & 155585209 \\
March 25, 2005 & 521880000 & 61.90 & 131357196 \\
March 6, 2006 & 741030000 & 87.90 & 186517251 \\
March 19, 2005 & 615360000 & 73.00 & 154886112 \\
\hline
\end{tabular}

But since the months December to February are very cold and no water runs over the basin, it was divided into nine months and became as $9.7 \mathrm{~mm}$ depth of water for each month. The final run off calculations of the basin is shown in Table 7. According to Table 7, there is no run off in February. The maximum is in May reaching to $43.5 \mathrm{~mm}$ and totaling to $120928075 \mathrm{~m}^{3}$. This value produces a water discharge of $46.6 \mathrm{~m}^{3} \mathrm{sec}^{-1}$.

Snow water from MODIS images: The snow melt water computed from MODIS images is written in Table 8 . The difference between this calculation and the one computed from temperature threshold is negligible. Because only $2.5 \%$ of the total snow is melted during colder months of December through February, this water can be accepted as the total snow water for the month March and backward. On the other hand, the snow cover decreases after March so that the melt water of March and later months can be accepted as more than $90 \%$ of the annual snow melt water.

\section{CONCLUSION}

Karaj Dam Reservoir Basin is located on the southern slope of the Alborz Mountains. The area receives most of its precipitation as snow in the cold season. The melted water of this snow is very important for dry period consumers such as local agriculture and Tehran city drinking water. In this research we tried to estimate the water budget of the basin through the use of MODIS images and the surrogate temperature thresholds. The temperature threshold was defined from 
the analysis of the daily temperature and precipitation of Nesa station as $3^{\circ}$ Celsius. Most of the melted snow water comes in March and afterward. Only $2.5 \%$ water was produced in the previous months. The comparison of the results with snow cover of the MODIS images showed that, it is possible to estimate the snow budget of the basin from these images.

\section{ACKNOWLEDGEMENT}

This research was funded by the financial support of the Tehran Regional Water Organization of the Ministry of Energy of Islamic Republic of Iran.

\section{REFERENCES}

1. Alijani, B., 1995. Climate of Iran. 1st Edn., Payame Noor University Publisher, Tehran, Iran, ISBN: 964-455-621-6, pp: 21-30.

2. Kramer, H.J., 2002. Observation of the Earth and Its Environment: Survey of Missions and Sensors. 4th Edn., Springer, Berlin, ISBN: 3-540-42388-5, pp: 791.

3. Klein, A.G., D.K. Hall and G.A. Riggs, 1998. Global snow cover monitoring using MODIS. Proceeding of the 27th International Symposium on Remote Sensing of the Environment, June, 812, Tromso, ISRSE, Norway, pp: 363-366. http://geog.tamu.edu/klein/publications/proceeding s/isrse_1998.pdf.

4. Salomonson, V.V. and I.L. Appel, 2004. Estimating fractional snow cover from MODIS using the normalized difference snow index. Remote Sens. Environ., 89: 351-360. DOI: 10.1016/j.rse.2003.10.016

5. Hall, D.K., G.A. Riggs, V.V. Salomonson, N.E. DiGirolamo and K.J. Bayr, 2002. MODIS snow-cover products. Remote Sens. Environ., 83: 181-194. DOI: 10.1029/2007WR006204

6. Klein, A.G., D.K. Hall and G.A. Riggs, 1998. Global snow cover monitoring using MODIS. Proceeding of the 27th International Symposium on Remote Sensing of the Environment, June, 812, Tromso, ISRSE, Norway, pp: 363-366. http://geog.tamu.edu/klein/publications/proceeding s/isrse_1998.pdf.

7. Salomonson, V.V. and I. Appel, 2006. Development of the aqua MODIS NDSI fractional snow cover algorithm and validation results. IEEE Trans. Geosci. Remote Sens., 44: 1747-1756. DOI: 10.1109/TGRS.2006.876029

8. Poon, S.K.M. and C. Valeo, 2006. Investigation of the MODIS snow mapping algorithm during snowmelt in the northern boreal forest of Canada. Can. J. Remote Sens., 32: 254-267. http://pubs.nrccnrc.gc.ca/cjrs/rs3-06.html
9. Hall, D.K., G.A. Riggs, V.V. Salomonson, N.E. DiGirolamo and K.J. Bayr, 2002. MODIS snow-cover products. Remote Sens. Environ., 83: 181-194. DOI: 10.1029/2007WR006204

10. Foster, J.L., G. Liston, R. Koster, R. Essery, H. Behr, L. Dumenil, D. Verseghy, S. Thompson, D. Pollard and J. Cohen, 1996. Snow cover and snow mass intercomparisons of general circulation models and remotely sensed datasets. J. Climate, 9: 409-426. DOI: 10.1175/1520-0442(1996)

11. Lina, X., S. Shi Jiancheng, Z. Hongen, W. Shengli, 2005. Fractional snow cover estimation in Tibetan Plateau using MODIS and ASTER. Proceeding of the IEEE International Symposium on Geoscience and Remote Sensing, IEEE Computer Society, Washington DC., USA., pp: 1940-1942. DOI: 10.1109/IGARSS.2005.1526390

12. Malcher, P., D. Floricioiu and H. Rott, 2003. Snow mapping in alpine areas using medium resolution spectrometric sensors. Proceedings of the IEEE International Symposium on Geoscience and Remote Sensing, July 21-25, IEEE Xplore, Toulouse, France, pp: 2835-2837. DOI: 10.1109/IGARSS.2003.1294603

13. Ghahroudi, T.M., 2005. GIS in Three Dimensional Environments. 1st Edn., Jihad Daneshgahi Publisher, Tehran, Iran, ISBN: 964-6653-32-4, pp: 16-24.

14. Seidel,K., J. Martinec, 2004. Remote Sensing in Snow Hydrology: Runoff Modelling, Effect of Climate Change. Springer, ISBN: 978-3-54040880-2, pp: 121.

15. Mahdavi, M., 1998. Applied Hydrology. 1st Edn., Tehran University Publisher, Tehran, Iran, ISBN: 964-03-9314-2, pp: 182-183.

16. Anbazhagan, S., S.M. Ramasamy and S.D. Gupta, 2005. Remote sensing and GIS for artificial recharge study, runoff estimation and planning in Ayyar basin, Tamil Nadu, India. Environ. Geol., 48: 158-170. DOI: 10.1007/s00254-005-1284-4

17. Gupta, R.P., U.K. Haritashya and P. Singh, 2005. Mapping dry/wet snow cover in the Indian Himalayas using IRS multispectral imagery. Remote Sens. Environ., 97: 458-469. DOI: 10.1016/j.rse.2005.05.010

18. Alavipanah, K., 2003. Use of Remote Sensing in Geological Sciences. 1st Edn., University of Tehran Publisher, Tehran, Iran, ISBN: 964-034788-4, pp: 97-117.

19. McCoy, J. and K. Johnston, 2001. Using ArcGIS in Spatial Analyst. 1st Edn., Esri Press, ISBN: 1-58948-005-6, pp: 61-65. 